\title{
Status and Challenges of Solid Waste Management in Beung Kiat Ngong Ramsar Site, Pathoumphone District, Champasack Province, Laos PDR
}

\author{
T. Khamkeo, S. Phaisansuthichol, P. Supapunt, and M. K. Pholchan
}

\begin{abstract}
Quantification and characterization of municipal solid waste are vital information for a proper solid waste management. However, these are under-investigated and scarcely implemented in Laos PDR, especially the local communities. This work, therefore, aimed to quantify and characterize municipal solid waste generated from Beung Kiat Ngong Ramsar Site and to recommend possible integrated solid waste management strategies for a sustainable waste management. The average daily waste generation was estimated to be $3.6 \mathrm{~kg} / \mathrm{day}$ and $2.6 \mathrm{~kg} / \mathrm{day}$ in Thabou village and Kiat Ngong village, respectively. Organic waste appeared to be the biggest component $(28 \%)$ for Thabou village, while packaging's dominated waste composition in Kiat Ngong village. Interestingly, high percentage of golden apple shells waste were mismanaged. These had the potential to convert into value-added products such as calcium carbonate $\left(\mathrm{CaCO}_{3}\right)$. It was found that fresh golden apple shells contained only 24.16 $\pm 0.48 \mathrm{~g} / \mathrm{l}$ as $\mathrm{CaCO}_{3}$, while incineration method increased higher $\mathrm{CaCO}_{3}$ products. The result showed that incineration at the temperature of $400{ }^{\circ} \mathrm{C}$ gave the highest amount of $\mathrm{CaCO}_{3}$ with the values of $1207.67 \pm 9.45 \mathrm{~g} / \mathrm{l}$ as $\mathrm{CaCO}_{3}$. Based on the resources and the strength of the Ramsar site, the production of value added material from bio-waste could be integrated into waste management strategies along with 3Rs policies implementation.
\end{abstract}

Index Terms-Beung Kiat Ngong Ramsar site (BKN), solid waste management, golden apple snail shells (GAS), calcium carbonate $\left(\mathrm{CaCO}_{3}\right)$.

\section{INTRODUCTION}

Solid waste problems have recently gained a lot of concerns as it has increased in volume all over the world due to population expansion, continuous economic growth, urbanization and industrialization. Approximately, 2.01 billion tonnes of municipal solid waste has been annually generated around the world and $33 \%$ of that are mismanaged. Between 1980 and 2005 solid waste generation within the OECD countries has increased by as much as $2.5 \%$ per year. The numbers of total solid waste generation are likely to increase by a further $1.3 \%$ in 2030 and expected to grow to 3.40 billion tonnes by 2050 .

The East Asia and Pacific region is generating most of the global waste (approximately $23 \%$ ). However, there is a positive correlation between waste generation and income

Manuscript received September 15, 2020; revised March 18, 2021. This work was supported by Thailand International Cooperation Agency (TICA).

The authors are with Maejo University, Thailand (corresponding author: M. K. Pholchan; e-mail: Thiddavanhkhamkeo@gmail.com, mujalin@mju.ac.th, sirirat@mju.ac.th, Patchari@mju.ac.th). level. High-income countries are predicted to increase by $19 \%$ by 2050 , whereas middle and low-income countries are expected to increase by $40 \%$ or more [1].

In recent years, different solid waste management strategies and policies have been proposed and implemented in developing countries, including Lao PDR. However, achieving the goals and finding effective sustainable solutions for each area is one of the greatest challenges. This is because there are factors affecting waste management that are technical, financial, social-cultural, organizational, and legal-political barriers and population growth [2].

There are several strategies have been proposed. Appropriate identification, collection, separation, storage, transportation, treatment, and disposal, as well as important associated aspects including awareness and training, become part of effective solid waste management. Integrating solid waste management model have been successfully implemented in many countries. Different development goals, policies and frameworks focusing on reduce, reuse and recycling are acceptable practices [3]. Economic and financial benefits of waste recycling, waste to energy and value- added products from organic waste have also gained a lot of interests recently. In addition, a fairer system based on the polluter-pays principle for the businesses sector, environmental education and environmental awareness campaigns are important and also needed to drive long term achievement [4].

Converting waste to value-added products is one of strategies for waste management that has become popular in the recent year. Several studies have been done to produce calcium carbonate from golden apple snail and oyster shells and used as the reinforcing filler for poly vinyl chloride (PVC) [5]. Some works reported using golden apple snail shell as calcium supplement source for Japanese quail production. It was found that egg production has been increased while the operation cost was reduced [6]. Golden apple snail shells have been reported to be used as an organic filler for silicone rubber insulator. The results revealed that higher value of dielectric constant as well as higher dielectric strength were obtained [7].

Beung Kiat Ngong (BKN) Ramsar site in Pathoumphone district, Champasack province is one of two wetlands that has been designated as the Ramsar site. This preserved and precious natural habitat requires sustainable development policy. Up until now, however, solid waste management at BKN Ramsar site is still inefficient and needed to be improved. Moreover, it is expecting that higher amount of waste will be generated due to higher populations and visitors. In order to plan and propose a suitable strategy for 
better solid waste management in BKN Ramsar site, it is necessary to quantify and characterize waste generation and composition [8]. The golden apple snail shells (Pomacea Caniculata) grows and reproduces very rapidly as one snail can produce $1000-1200$ eggs/ month with $80 \%$ hatchability [9]. Entrepreneurs have envisioned a profitable mass production of the golden apple snail shells as human food. This new exotic species has become a popular business among people living nearby Ramsar site. Apart from inefficient household and agricultural waste management, amount of shells has been developed with approximately 98,549 $\mathrm{kg}$ per year and still mismanaged. Therefore, the objectives of this study were to quantify and identify waste generation at BKN Ramsar site, Pathoumphone district, Champasack province, Laos PDR and propose the possible strategy for sustainable solid waste management, including golden apple snail shell. This study will be helpful to policymakers in designing a better and more efficient waste management systems.

\section{MATERIALS AND METHODS}

\section{A. The Study Areas}

The Beung Kiat Ngong Ramsar site (BKN) Ramsar site is located in Pathoumphone district, Champasak Province, Laos, PDR. It is about $56 \mathrm{~km}$ south of Pakse city and lies between $14^{\circ} 43^{\prime} 02^{\prime \prime} \mathrm{S}$ latitude and $14^{\circ} 43^{\prime} 53^{\prime \prime} \mathrm{E}$ longitude. (as shown in Fig. 1). It has approximately 2,360 hectares. BKN Ramsar site has eight villages where two villages that were Thahou village (agricultures area) and Kiat Ngong village (tourist site area) were selected in this study. The solid waste from landfills of both different areas were collected and mixed before sorting using quartering method [10]. This waste was then characterized. The percentage of each constituent and bulk density were then calculated as explained elsewhere. Moreover, secondary data regarding solid waste generation, collection system and disposal methods were collected from department of natural resources and environment in Champasack province.

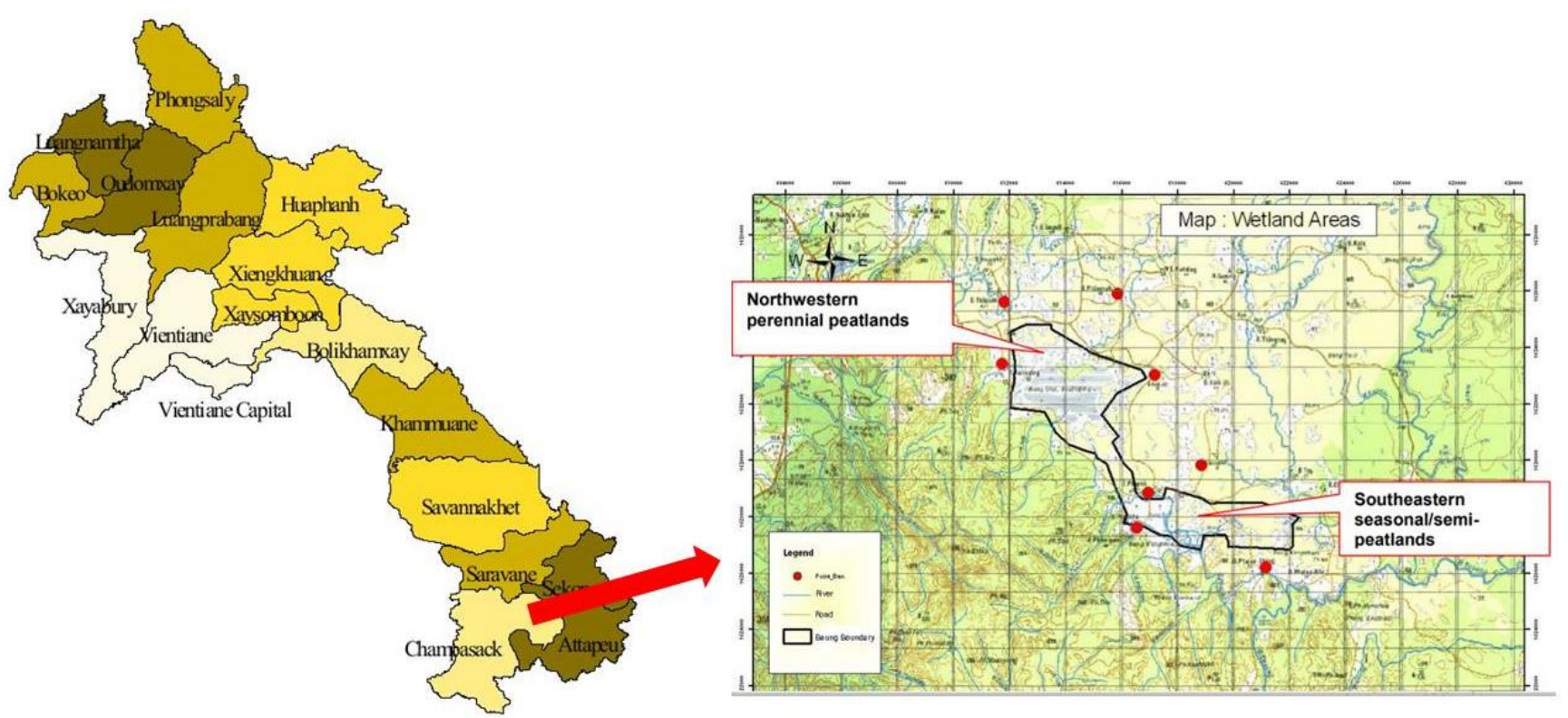

Fig. 1. Location of the study area (BKN, Laos PDR).

\section{B. Experimental Set up for Obtaining $\mathrm{CaCO}_{3}$ from} Golden Apple Snail Shells (GAS)

Golden apple snail shells (GAS) were collected and approximately $2.7 \mathrm{~kg}$ of GAS were prepared by cleaning and air drying. Three treatments as shown from Fig.2 were conducted to find the best process for obtaining $\mathrm{CaCO}_{3}$ from GAS. In treatment A, GAS was crushed into small pieces before incineration, while GAS from treatment B was burned directly without crushing. Treatment $\mathrm{C}$ was the control which was the fresh shells with no crushing and burning. GAS with triplicates were put into the incinerator for 1 hour with the temperatures varied at $400{ }^{\circ} \mathrm{C}, 500{ }^{\circ} \mathrm{C}$ and $600{ }^{\circ} \mathrm{C}$. The $\mathrm{CaCO}_{3}$ obtained was then identified.

\section{C. $\mathrm{CaCO}_{3}$ Analysis}

Calcium Carbonate $\left(\mathrm{CaCO}_{3}\right)$ contained in GAS samples from three treatments was analyzed using EDTA Titrimetric Method. 6M of $\mathrm{HCl}$ was added into $0.1 \mathrm{~g}$ of GAS until it was completely dissolved. It was then adjusted to $100 \mathrm{ml}$ using acid solution before titrated with EDTA standard solution using murexide as an indicator (as explained elsewhere). The volume of EDTA used for titration (in milliliters) was multiplied by 20 to get the calcium Carbonate value in $\mathrm{mg} / \mathrm{L}$ as $\mathrm{CaCO}_{3}[11]$.

\section{Statistical Data Analysis, SPSS}

SPSS Anova was used to compare the statistically significant phase between experiments where $\mathrm{CaCO}_{3}$ was obtained under different temperatures and different GAS preparation patterns. The size of the selected sample was calculated for a level of confidence of $95 \%$ with an error range of $5 \%$.

\section{RESULTS AND DISCUSSION}

Based on the aforementioned analytical procedures the 
following results have been found:

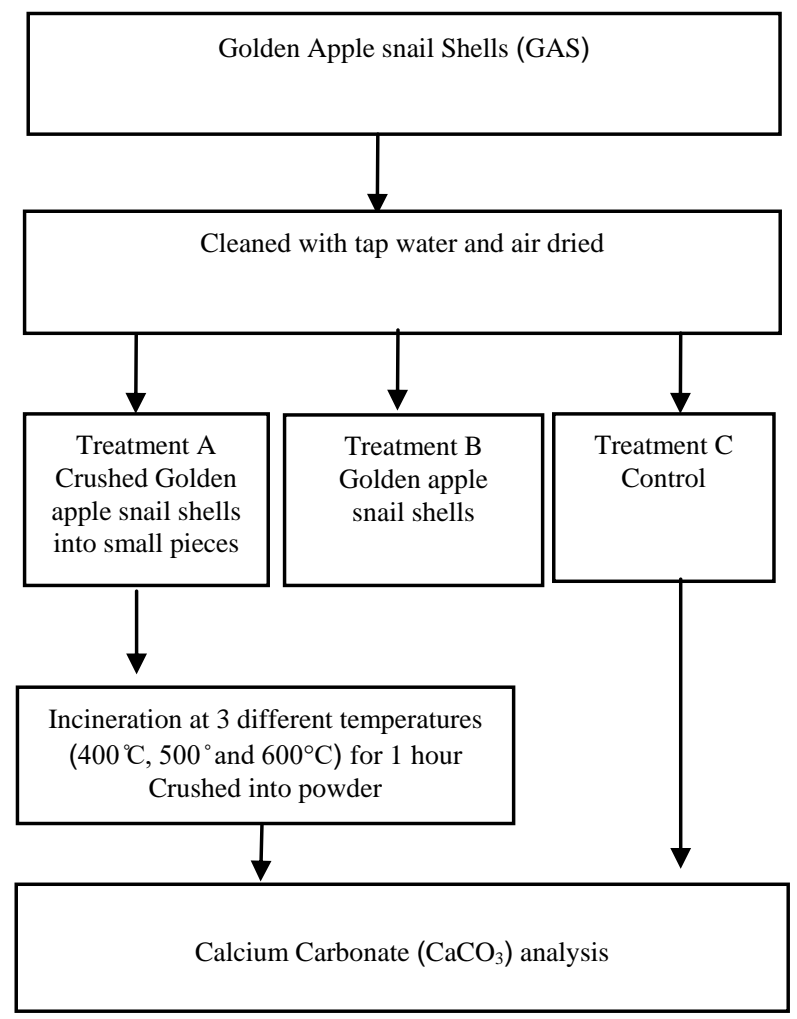

Fig. 2. Flow diagram of experimental design.

\section{A. Waste Generation and Characteristics}

BKN Ramsar site has provided enormous direct and indirect benefits for local communities. It was estimated in 2011 that the wetlands provided US\$ 897,607 of annual direct economic values. Besides, the information from department of information and tourisms in Champasack province from 2013 to 2017 reported that the number of tourists has increased to 20,000 persons and tended to be rising. As a result, higher amount of solid waste has been generated in this areas.

Currently, Thahou village has 85 households with 224 populations, while Kiat Ngong village has 172 households with 431 populations in the community. The majority of the population are farmers who mainly engage in paddy rice cultivation and earn some extra income from tourisms. The results indicated that only $10 \%$ of solid waste were dumped into the community landfill while $90 \%$ were golden apple snail shells that were open dumped everywhere in both areas.

During sampling in year 2020, it was found that Thahou village generated a daily average solid waste of $3.6 \mathrm{~kg} / \mathrm{day}$, while Kiat Ngong generated $2.3 \mathrm{~kg} /$ day. This numbers excluded food waste and agricultural waste which were used as raw materials for composting. It can be seen that the amounts of waste from both villages, which are local areas, are less than the one from the big city of Lao, PDR. This represents the low income and way of life in the local community. However, waste generation from both areas showed variation by locations, sources, and activities. In comparison with tourist site area in Thailand, it generates a low rate of approximately $0.3 \mathrm{~kg} / \mathrm{day}$. The differences could be either as a result of income level, economic and consumption habit or disposal habits of people.

As seen from the Fig.3, organic waste forms the biggest component of solid waste generated in Thabou village which is about $28 \%$. This is due to fallen leaves from trees or garden wastes and agriculture residues generated in this area. Normally, these wastes were managed by open burning. On the other hand, the lowest composition was found from paper, hazardous waste and milk can which is only $9 \%$ of total of solid waste. Most of the waste generated from Thabou village come from nature due to it is agricultural area which is far from markets. This is completely opposite to Kiat Ngong village where plastic dominated waste composition showing the largest proportion of $29 \%$. It is also followed by milk can and foam which were $22 \%$ and $21 \%$ respectively. The major contributing factor of waste composition of this area is that it is the tourist destination where packaging has been used and generated with no or little recycling mechanisms.

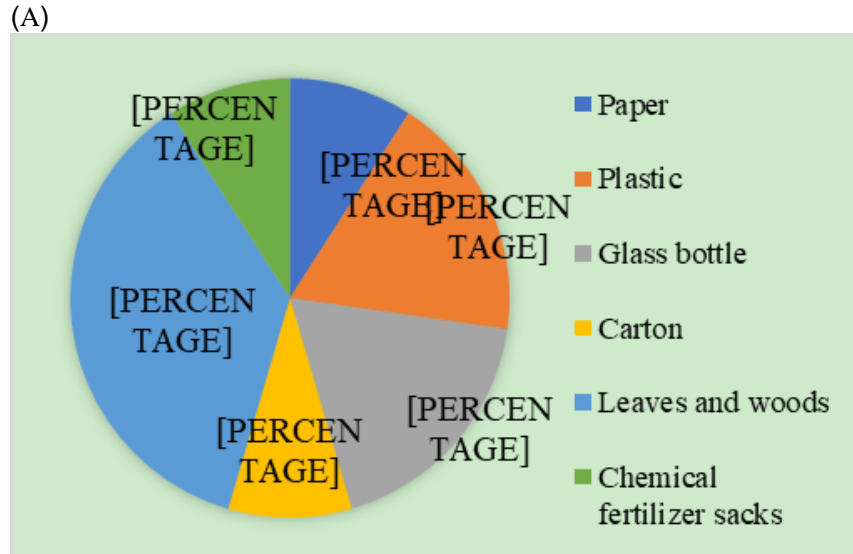

(B)

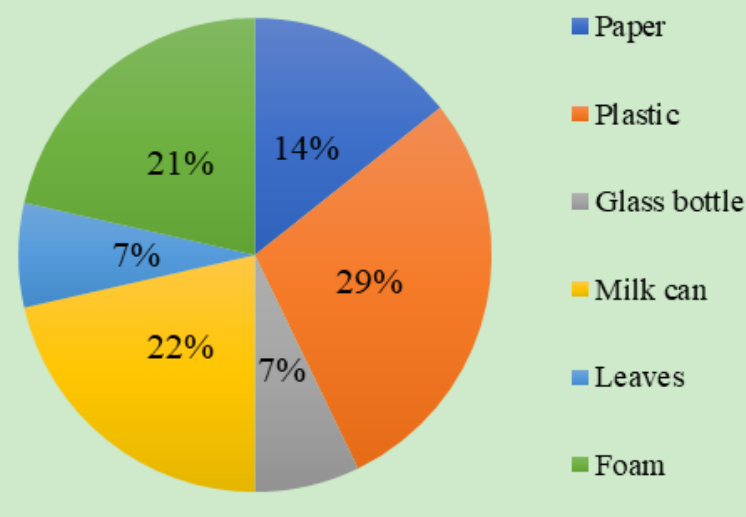

Fig. 3. Percentage waste composition in Thabou village (A) and in Kia Ngong village (B).

Interestingly, large amount of golden apple snail shells was found from both villages which approximately 98,549 $\mathrm{kg}$ / year. It appeared that this exotic species has become popular as high number of customers have increased. The income from selling golden apple snail shells in Pathoum phone market and DaoHeung market (in Pakse city) was as high as US\$287,000 per year (1 kg per $1 \mathrm{US \$}$ ) [3]. However, there is no disposal strategy, they were open dumped everywhere in these areas which seems to be a big environmental problem in the very near future. 


\section{B. $\mathrm{CaCO}_{3}$ from $\mathrm{GAS}$}

In order to convert GAS into the value -added product, which is $\mathrm{CaCO}_{3}$, three different treatments were compared. It was found that there was a significant difference of the amount of calcium carbonate obtained between the control (fresh shells with no treatment) and shells after incineration ( $P \geq 0.05$, ANOVA). Moreover, one-way ANOVA revealed statistically significant difference of calcium concentration between different burning temperature. It was found that fresh golden apple snail shells contained $24.16 \pm 0.48 \mathrm{~g} / \mathrm{L}$ as $\mathrm{CaCO}_{3}$. However, the method of burning GAS before crushing into powder (treatment B) significantly increased the amount of calcium carbonate as shown in Fig 4. The result showed that higher temperature reduced the amount of calcium carbonate, while burning GAS at lowest temperature $\left(400^{\circ} \mathrm{C}\right)$ gave highest amount of calcium carbonate with the value of $1207.67 \pm 9.45 \mathrm{~g} / \mathrm{L}$ as $\mathrm{CaCO}_{3}$ and $304.92 \pm 4.74 \mathrm{~g} / \mathrm{L}$ as $\mathrm{CaCO}_{3}$ for treatment $\mathrm{B}$ and $\mathrm{A}$, respectively. Moreover, \% yield obtained from both treatments (A and B) was found to be in the range of 93-96\% (Table I). Also, the result showed that treatment $\mathrm{B}$ with incineration temperature at $400{ }^{\circ} \mathrm{C}$ gave highest $\%$ recovery with the value up to $96 \%$.

TABLE I: GAS BIOMASS AND \% YIELD OBTAINED FROM THREE TREATMENTS (A-CRUSHED BEFORE INCINERATIED, B-INCINERATED WITHOUT CRUSHING AND C-CONTROL)

\begin{tabular}{|c|c|c|c|c|}
\hline Treatments & Incineration temperature & $\begin{array}{c}\text { Amount (mg) } \\
\text { Before incineration }\end{array}$ & $\begin{array}{c}\text { Amount (mg) } \\
\text { After incineration }\end{array}$ & $\%$ Yield \\
\hline \multirow{2}{*}{ A } & $400^{\circ} \mathrm{C}$ & $201.48 \pm 0.31$ & $192.98 \pm 1.03$ & 95.7 \\
\hline & $600^{\circ} \mathrm{C}$ & $200.58 \pm 0.25$ & $191.86 \pm 0.21$ & 95.7 \\
\hline \multirow[b]{2}{*}{ B } & $400^{\circ} \mathrm{C}$ & $201.08 \pm 0.27$ & $193.54 \pm 0.41$ & 96.2 \\
\hline & $500^{\circ} \mathrm{C}$ & $201.28 \pm 0.49$ & $190.12 \pm 1.07$ & 94.5 \\
\hline $\mathrm{C}$ & & $198.52 \pm 0.24$ & & \\
\hline
\end{tabular}

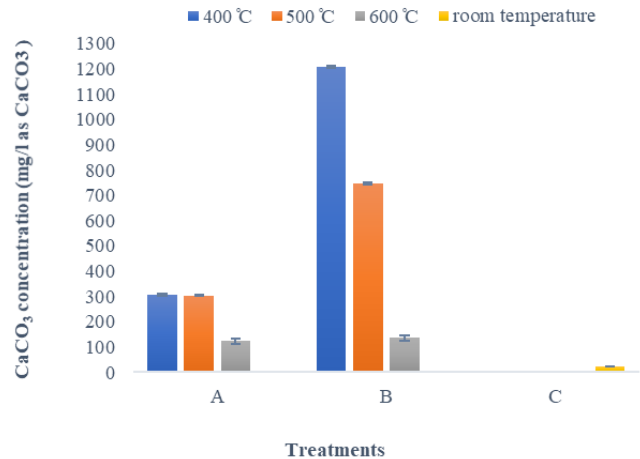

Fig. 4. Average concentration of $\mathrm{CaCO}_{3}$ obtained from GAS between 3 treatments (A-crushed before incineration, B-incineration without crushing and C-control).

C. Recommendations for Driving Sustainable Solid Waste Management

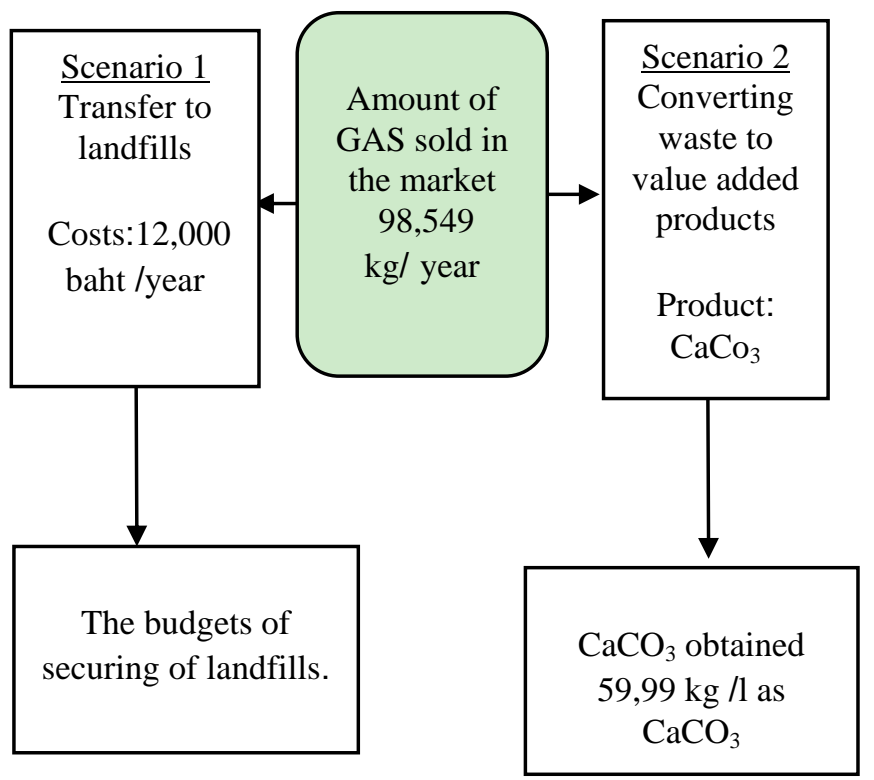

Fig. 5. Strategy of converting GAS into value $\mathrm{CaCO}_{3}$.
The characterization of solid waste in Ramsar area is the basis for sustainable solid waste management planning. Currently, the results showed that there is no separation at the source for compostable/organic waste from non-biodegradable wastes and everything have been dumped to the landfill. Also, the disposal practices of waste collecting, and management were not sustainable and open burning have been found. Based on the information obtained from above, a plan for strategies to prevent, reduce, separation, collect, recycle and value - added products becomes more effective for both areas as shown in Fig.5.to Fig.7.

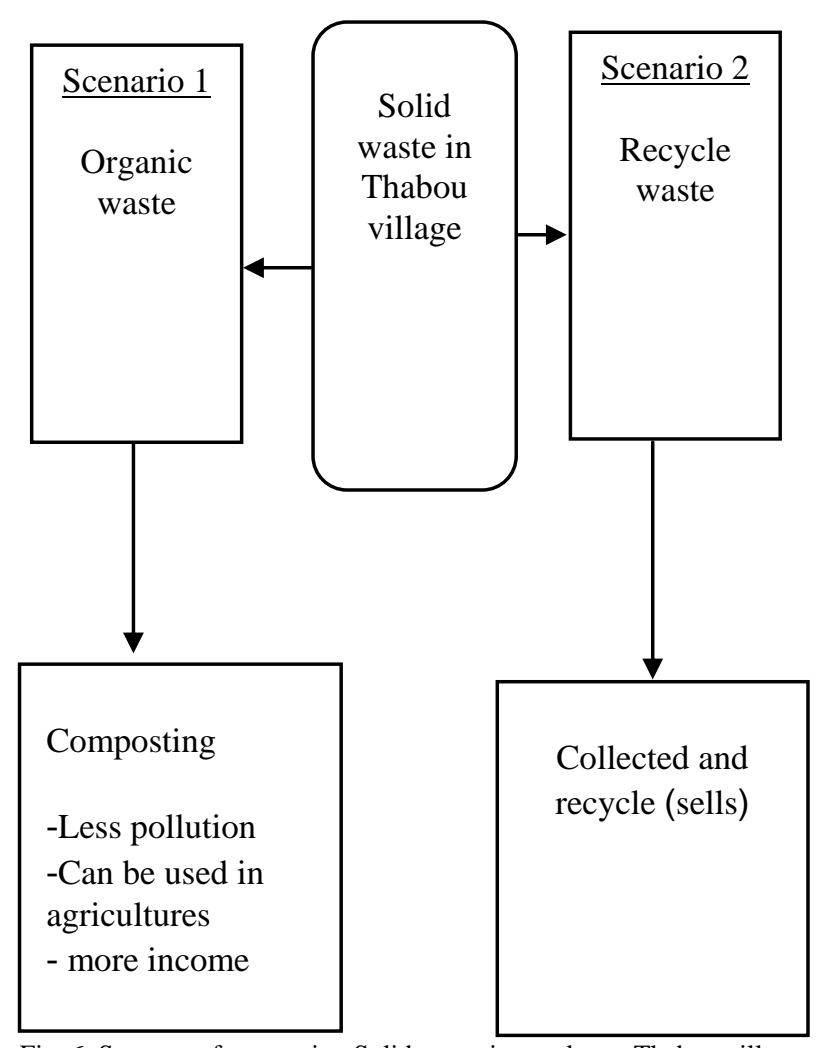

Fig. 6. Strategy of converting Solid waste into value at Thabou village. 
In order to drive the improvement of solid waste management in the Ramsar site, it is important to develop zero waste policies and green strategies by encouraging reduction at the point of generation, implementing reuse and recycle programs for paper, plastics and other recyclable packaging, especially at the tourist destination area. Separate containers for different waste categories should be provided at the collection points. On the other hand, the application of composting for soil enrichment or feedstock for biogas production should be considered for organic waste management from the agriculture area.

Furthermore, converting waste into value added product is also one of the potential strategies for GAS management (Fig. 5). Every year GAS peels were generated in BKN Ramsar site as much as $98,549 \mathrm{~kg} /$ year. If there is no policy, the community will have to spend approximately 12,000 baht/ year for transferring these wastes to landfills which is quite costly for people living in this area considering that low GDP 2,534.9 \$ per year/person (GDP in 2019, Laos PDR) has been reported [12]. However, adding the values into GAS by converting into $\mathrm{CaCO}_{3}$, approximately $59.99 \mathrm{~kg} / \mathrm{L}$ as $\mathrm{CaCO}_{3}$ was produced as a replacement of $\mathrm{CaCo}_{3}$ from bones or limestone. It can be used for many industrial production processes and agricultural sectors [8]. This can be an extra business and give more income for people in the Ramsar site area because the price of $\mathrm{CaCO}_{3}$ powder $(\mathrm{CaCO} 3$ from naturally Grade A) is around 107 baht/ $250 \mathrm{~g}$ [13]. Therefore, $\mathrm{CaCO}_{3}$ produced from this amount of GAS generated could be around 80,468 baht.

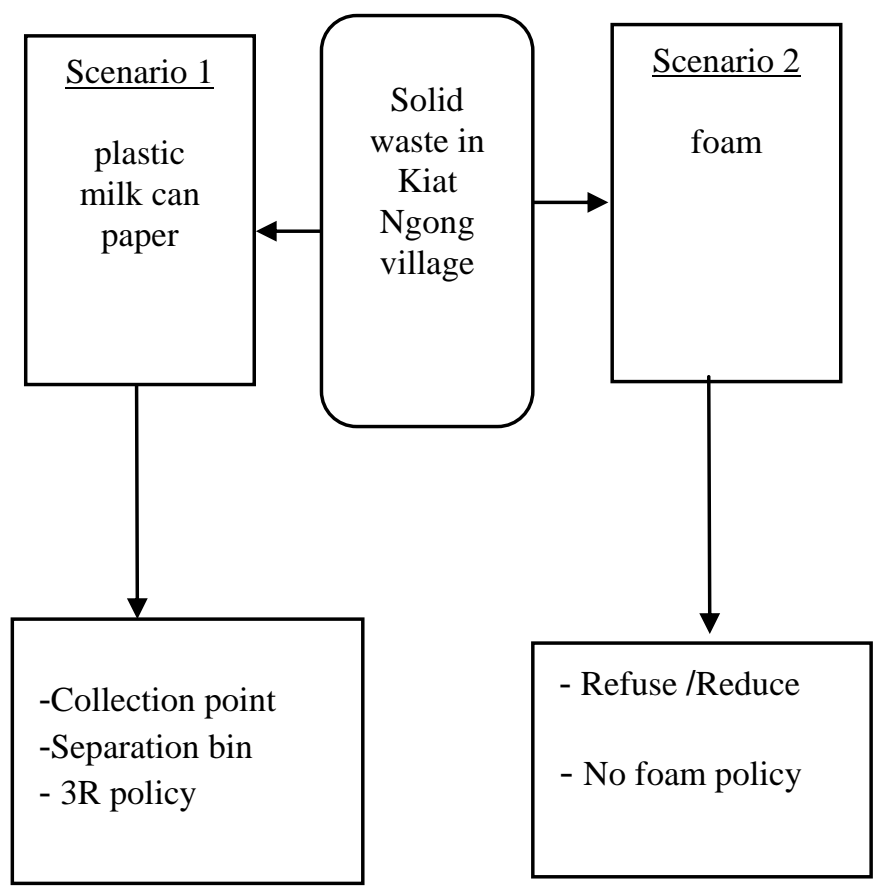

Fig. 7. Strategy of converting Solid waste into value at Kiat Ngong village.

\section{CONCLUSION}

This work highlighted solid waste issues and management challenges in BKN, Pathoumphone district, Champasack province, Laos PDR. The result indicated that composition of waste varied between site and location, income and activities. It was also recommended that strategic policy framework and community awareness and involvement and participation are imperative for reduction, recycling, reuse, composting and value-added production. If appropriate solid waste policies and technologies are introduced, people living in ramsar site can have better quality of life and more income while the natural ecosystem can be preserved.

\section{CONFLICT OF INTEREST}

The authors declare no conflict of interest.

\section{AUTHOR CONTRIBUTIONS}

Thiddavanh Khamkeo is studying at master's degree of environmental of technology in Maejo University, who performed the experiments, analyzed, interpreted the data, write a paper. Mujalin Pholchan is the corresponding author for this manuscript who advised, conceived, designed the experiments, and wrote and edited the manuscript. Sirirat Phaisansuthichol contributed chemical and analytical tools and supports while Patcharin supapunt contributed tools for economic worthiness analysis.

\section{ACKNOWLEDGMENT}

This research was financially supported by Thailand International Cooperation Agency (TICA). The authors would also like to thank the faculty of science, Maejo university for providing all equipment and lab technicians for supports and technical insights.

\section{REFERENCES}

[1] K. Mintz, L. Henn, J. Park, and J. Kurman, "What predicts household waste management behaviors? Culture and type of behavior as moderators," Resources, Conservation \& Recycling, pp. 11-18, January 2019.

[2] N. Yukalang, B. Clarke, and K. Ross, "Barriers to effective municipal solid waste management in a rapidly urbanizing area in Thailand," Int J Environ Res Public Health, vol. 14, no. 9, p. 1013, Sep. 2017.

[3] A.Challcharoenwattana and C. Pharino, "Wishing to finance a recycling program? Willingness-to-pay study for enhancing municipal solid waste recycling in urban settlements in Thailand," Habitat International, vol. 51, pp. 1-8, October 2015.

[4] Y. Suma, N. Pasukphun, A. Hongtong, V. Keawdunglek, P. Laor, and T. Apidechkul, "Waste composition evaluation for solid waste management guideline in highland rural tourist area in Thailand," Applied Environmental Research, pp. 1-14, March 2019.

[5] N. Runpin, "Nano Calcium carbonate fromgolden apple snail and oyster shells as reinforcingfiller," Chulalongkorn University Intellectual Repository, pp. 5-91, 2011.

[6] S. Petchpankan, M. Chamnangategrone, and J. Srisawat, "Utilization of golden apple snail shell flour as calcium supplement in laying japanese quail," pp. 1-9, 2019.

[7] S. Tepsila and A. Suksri, "Organic filler from golden apple snails shells to improve the silicone rubber insulator properties," Earth and Environmental Science, pp. 1-8, 2018.

[8] IUCN, Management plan of the Beung Kiat NgongRamsar site, Pathoumphone District, Champassak Province, Lao PDR, On IUCN, Gland, Switzerland, and Vientiane, pp. 8-39, 2017

[9] R. H. Cowie, "The golden apple snail: Pomacea species including Pomacea canaliculata Center for conservation research and training," University of Hawaii, pp. 18-30, 1822.

[10] Scimath. (2019). The definition of behavior. [Online]. Available: https://www.scimath.org/

[11] Department of Fisheries. (2020). The analysis principle of found $\mathrm{CaCO}_{3}$ by process of EDTA titrimetric method. [Online]. Available: https://www.fisheries.go.th/cf-chan/index.htm

[12] World Development Indicators. [Online]. Available: https://databank.worldbank.org/reports.aspx? source=2\&series=NY.G DP.PCAP.CD\&country=LAO\#

[13] Amazon. (2020). Grade A-Calcium Carbonate. [Online]. Available: https://www.amazon.in/PMW-Calcium-Carbonate-Powder/dp/B07FZ K5HHR 
Copyright $\odot 2021$ by the authors. This is an open access article distributed under the Creative Commons Attribution License which permits unrestricted use, distribution, and reproduction in any medium, provided the original work is properly cited (CC BY 4.0).

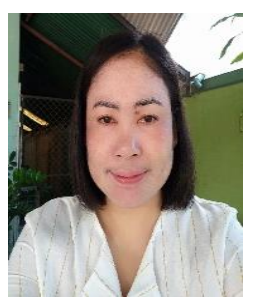

Thiddavanh Khamkeo has received certificate of meteorology and hydrology 2007-2009 in Vientiane Laos PDR, diploma on English in Pakse in Teacher Training College, the bachelor degree on English in Champasack University, Laos PDR and she worked in meteorology and hydrology section of Champasack province in April 2003 to 2007, worked at assistant for JICA team at Department of Meteorology and Hydrology in Vientiane 1 year, on 07/01/2014 to 31/12/2014 was a Junior Riparian Professional under the flood Management and Mitigation program in Mekong River Commission Secretariat in PhnomPenh, Cambodia. In 2014 to 2018 worked at Department of Natural Resources and environment in Champasack province under the project Lower Mekong Basin Wetland Management and Conservation Project or Mekong Regional Wetland Project (MRWP-KFW). Now she is studying at master's degree of environmental of technology in Maejo University.

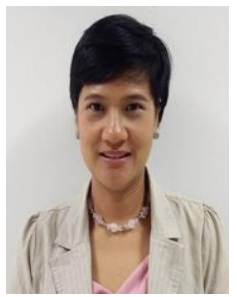

Mujalin K. Pholchan received the Ph.D. degree in environmental engineering from University of Newcastle upon Tyne, UK in 2007. She is currently acting as head of program in Environmental technology and has been working as a lecturer for master of science program in Environmental technology and also BSc, MSc and PhD program in Biotechnology majoring in environmental biotechnology, Faculty of Science, Maejo University (MJU). She is in charge of teaching several subjects such as pollution treatment technologies, solid and hazardous waste disposal and management, bioenergy from organic waste and also wastewater treatment control and monitoring. She has been actively involved in the research related to sustainable waste and wastewater treatment from agroindustry with 20 publications on international and national journals and proceedings. Her research focuses on biological treatment process, waste to energy and value-added waste utilization. In 2019, moreover, she also was appointed as a team leader in waste management team of MJU Green university committees who are responsible for planning and setting up solid waste management policies, programs campaigns, and activities related to Green /Eco University.

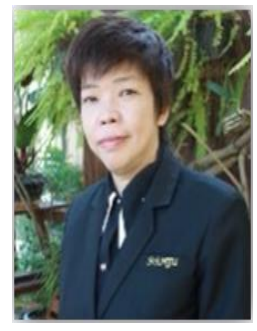

Sirirat Phaisansuthichol received the $\mathrm{PhD}$ degree in chemistry from Walailak University, Nakhon S Thammarat, Thailand in 2011. She is currently an associate professor with the Department of Chemistry, Faculty of Science, Maejo University, Chiang Mai, Thailand. She is an author of more than 10 research papers published in both national and international journals, and Her main filed of research interests include food, drugs, antioxidant in vegetable and fruits and residue in the environment.

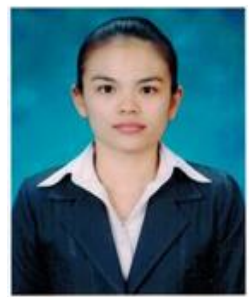

Patcharin Supapunt has received a Ph.D. agricultural system, M. S. agricultural economics, B.S. in agricultural economics, Chiang Mai University, Thailand. She is now an assistant professor and acting as an assistant dean of academic affairs, Faculty of economics, Maejo University. Currently, she is teaching at the Department of Agricultural, Resource and Environmental Economics and her expertise related to agricultural Economics and agricultural system and worthiness analysis. She has publications from both national and international papers more than 5 . 